\title{
Granulomatous mastitis: a report of seven cases
}

\author{
A FLETCHER, ${ }^{*}$ IM MAGRATH,$\dagger$ RH RIDDELL,$\ddagger$ IC TALBOT* \\ From the *Department of Pathology, Clinical Sciences Building, Leicester Royal Infirmary, POB65, Leicester \\ LE2 $7 L X$, the Croydon Area Laboratory, Mayday Hospital, Mayday Road, Thornton Heath, Surrey, \\ CR4 6YE, and the $\ddagger$ Department of Pathology, University of Chicago, 950 East 95th Street, Chicago, Illinois, \\ USA 60637
}

SUMMARY The clinical history and histological features of seven cases of granulomatous mastitis are presented. The lesion occurs in young parous women as a tender extra-areolar breast lump. Histologically, non-caseating discrete granulomas are present, confined to breast lobules with, in three cases, coalescence of the granulomas and microabscess formation. Pathogenesis of the changes is discussed. It is thought that granulomatous mastitis is an entity morphologically distinct from duct ectasia/plasma cell mastitis and the commoner forms of granulomatous breast diseases.

A granulomatous inflammatory response can be a reaction to either a specific agent-for example, Mycobacterium tuberculosis or a characteristic of a disease-for example, sarcoidosis. Five patients with breast nodules showing such a reaction, yet unrelated to any specific infection, trauma or foreign material, were reported by Kessler and Wolloch ${ }^{1}$ in 1972. They found a discrete granulomatous lobulitis and because of the morphological resemblance to granulomatous thyroiditis and orchitis, suggested that it might be immunologically mediated. Since their publication further reports have appeared; Cohen $^{2}$ reported five cases, Koelmeyer and MacCormick $^{3}$ two cases and Brown and Tang ${ }^{4}$ two further cases. Descriptions have not appeared in the European literature, recent editions of standard textbooks of pathology and a more specialised treatise with the exception of Azzopardi's recent book. ${ }^{5}$ The older literature contains many descriptions of the pathology of chronic mastitis, some emphasising the plasma-cell infiltrate, ${ }^{6}$ others the presence of foreign-body giant cells, ${ }^{7}$ but none mention a granulomatous reaction in a lobular distribution. We therefore wish to present the clinical details and histology of seven further cases of this evidently poorly recognised condition, from our routine biopsy pathology service.

\section{Report of the cases}

The individual patients' clinical details are summarised in Table 1 . They were all young, parous and all

Accepted for publication 20 January 1982
Table 1 A summary of the main clinical details from patients presenting with an extra-areolar, painful swelling of about four weeks duration

\begin{tabular}{lllllll}
\hline & $\begin{array}{c}\text { Age } \\
\text { (yr) }\end{array}$ & Parity & $\begin{array}{c}\text { Time since } \\
\text { last pregnancy } \\
\text { (months) }\end{array}$ & Breast & \multicolumn{2}{l}{ Lymph nodes } \\
\cline { 5 - 6 } & & & & Enlarged & Painful \\
\hline 1 & 31 & 6 & 24 & R & - & - \\
2 & 32 & 2 & 2 & L & - & + \\
3 & 22 & 5 & 6 & L & - & - \\
4 & 25 & 2 & 12 & R & - & - \\
5 & 29 & 2 & 78 & R & - & - \\
6 & 42 & 4 & 12 & R & - & - \\
7 & 23 & 1 & 1 & L & - & - \\
\hline
\end{tabular}

presented within six years of a pregnancy with a painful extra-areolar swelling. None had breast fed their most recent infant and there was no constant history of oral contraceptive use. There was no prediliction for any particular site within the breast and only one patient had tender axillary lymph nodes which were not clinically enlarged. After surgical excision of the swelling three out of five patients for which follow-up information is available developed superficial wound infections in the subsequent 10 months. All responded to antibiotics or drainage. One patient (case 7) developed a further breast mass requiring re-excision and an indurated area developed in the opposite breast. Culture of tissue failed to grow any pathogens or mycobacteria. She was treated with steroids and the lesion gradually resolved.

The main histological feature, present in all seven cases, was a granulomatous inflammatory response affecting the breast lobules (Fig. 1). The granulomas were composed of epithelioid histiocytes, with occa941 


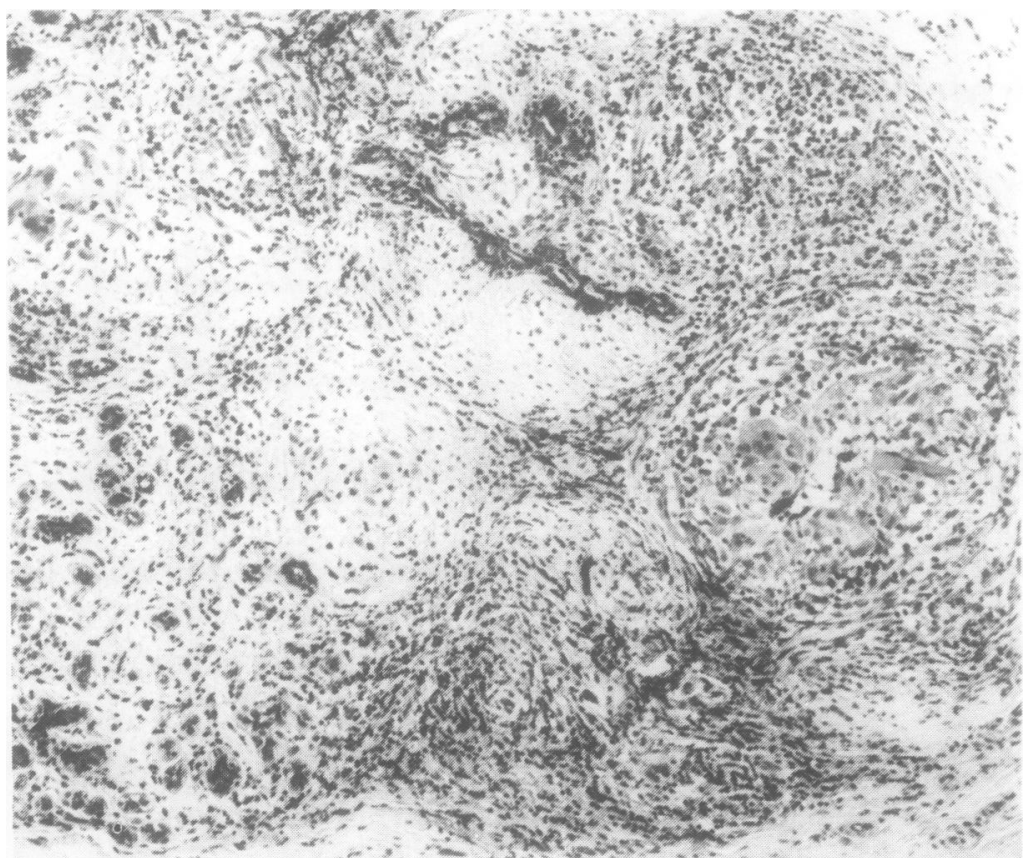

Fig. 1 Breast tissue showing inflammation centred on a lobule, with discrete granulomas (containing Langhans-type multinucleate cells). Haematoxylin and eosin $\times 400$

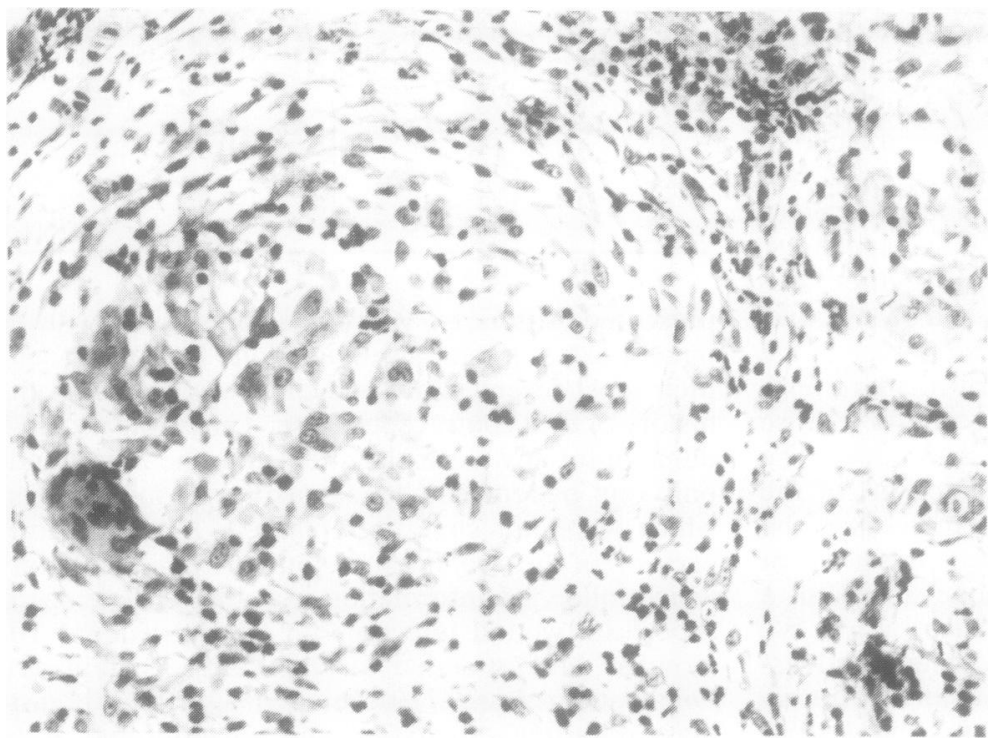

Fig. 2 Part of a breast lobule, showing discrete granulomas with multinucleate cells, and occasional polymorphs. Haematoxylin and eosin $\times 600$

sional Langhans-type multinucleate giant cells, eosinophils and scanty collections of polymorphonuclear leucocytes (Fig. 2). They were usually small, well circumscribed and confined to the lobules, but in three of the cases there was obliteration of the lobular architecture by sheets of epithelioid cells and microabscesses were present
(Fig. 3). In two of the cases marked ductular damage was present, with ulceration of the ductular epithelium and polymorphs in the lumen (Fig. 4). Outside the microabscesses, there were no areas of necrosis or caseation within any of the granulomas. No refractile material was found. Ziehl-Neelsen and periodic-acid Schiff stains were done and in none of 


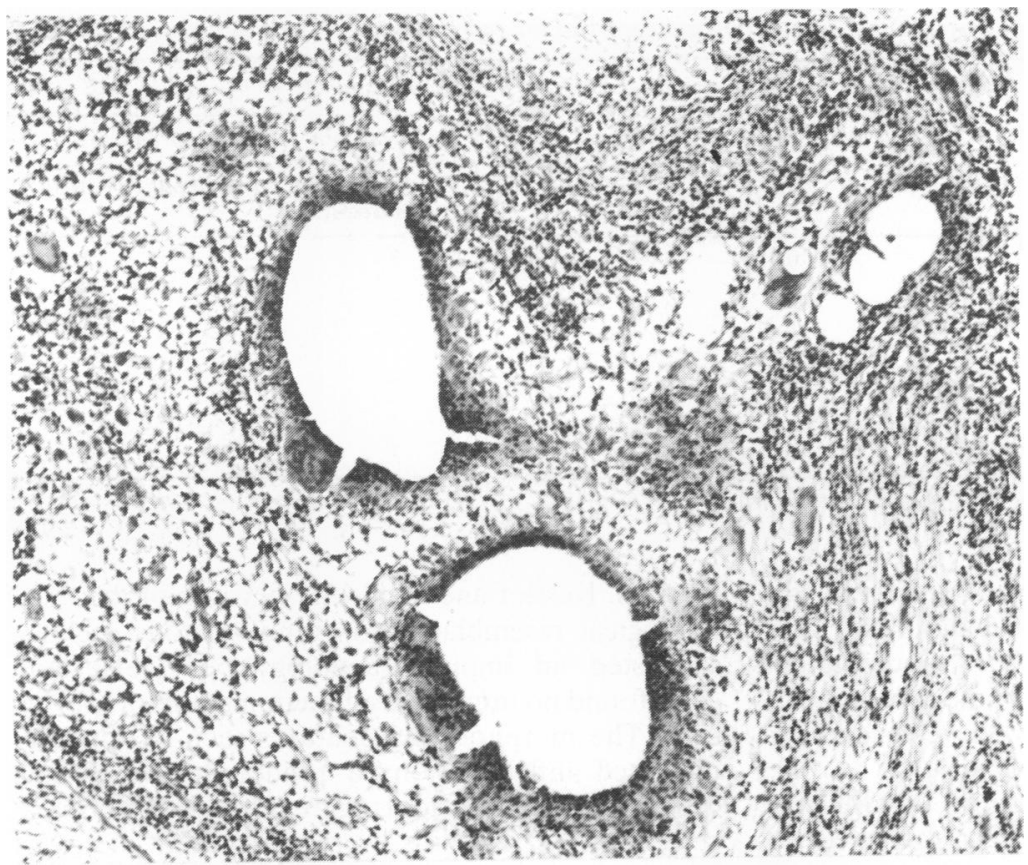

Fig. 3 An area of confluent granulomas, with microabscess formation centred on breast lobules. Haematoxylin and eosin $\times 400$

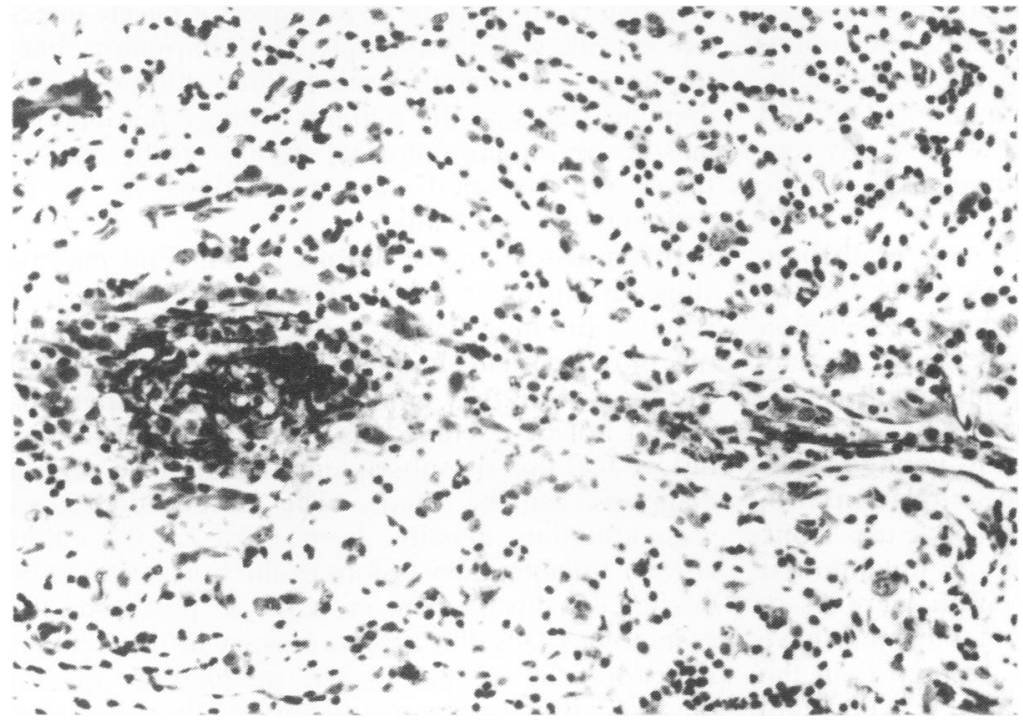

Fig. 4 A breast ductule showing damaged epithelium with epithelial ulceration and polymorphs in the lumen. The surrounding acini are undergoing atrophy. Haematoxylin and eosin $\times 700$

the patients was there any clinical or histological evidence of tuberculous infection or sarcoidosis. The re-excision specimen in case 7 showed a granulomatous lobulitis similar to the original biopsy but with marked microabscess formation.

\section{Discussion}

The clinical findings of a painful extra-areolar nodule occurring in young, parous women, composed histologically of granulomatous lobulitis 
Table 2 A summary of the clinical details and histological appearances of all the reported cases of granulomatous mastitis

\begin{tabular}{|c|c|c|c|c|c|c|c|c|c|c|c|}
\hline \multirow[t]{3}{*}{ Authors } & \multirow{3}{*}{$\begin{array}{l}\text { No of } \\
\text { cases }\end{array}$} & \multirow{3}{*}{$\begin{array}{l}\text { Age } \\
\text { range } \\
(y r)\end{array}$} & \multirow[t]{3}{*}{ Parity } & \multirow[t]{3}{*}{ Pain } & \multirow{3}{*}{$\begin{array}{l}\text { Extra- } \\
\text { areolar } \\
\text { site }\end{array}$} & \multicolumn{2}{|c|}{ Axillary lymph nodes } & \multicolumn{4}{|c|}{ Histological appearance: No of cases in each report } \\
\hline & & & & & & \multirow[t]{2}{*}{ Tender } & \multirow[t]{2}{*}{ Enlarged } & \multirow{2}{*}{$\begin{array}{l}\text { Discrete } \\
\text { granulomas }\end{array}$} & \multirow{2}{*}{$\begin{array}{l}\text { Confuent } \\
\text { epithelioid } \\
\text { cells/micro } \\
\text { abscesses }\end{array}$} & \multicolumn{2}{|c|}{ Ductular changes } \\
\hline & & & & & & & & & & Inflammation & Misc* $^{*}$ \\
\hline $\begin{array}{l}\text { Kessler and } \\
\text { Wolloch' }\end{array}$ & 5 & $23-42$ & $2-6$ & + & + & 0 & 1 & 5 & 3 & - & 2 \\
\hline Cohen ${ }^{2}$ & 5 & $17-34$ & - & - & + & - & 0 & 5 & 2 & - & 4 \\
\hline $\begin{array}{l}\text { Brown and } \\
\text { Tang }{ }^{4}\end{array}$ & 2 & $32-35$ & $2-4$ & + & + & 1 & 1 & 2 & 1 & - & - \\
\hline $\begin{array}{l}\text { Koelmeyer and } \\
\text { MacCormick }\end{array}$ & 2 & $24-26$ & $1-2$ & + & + & 0 & 1 & 2 & - & - & 1 \\
\hline Miller ${ }^{\circ}$ & 1 & 33 & - & - & + & 0 & 0 & 1 & - & 1 & 1 \\
\hline Present report & 7 & $22-42$ & $1-6$ & + & + & 1 & 0 & 7 & 3 & 2 & 0 \\
\hline
\end{tabular}

*Ductular dilatation, squamous metaplasia.

accords well with the features previously reported (Table 2). In the absence of clinical and histological evidence of an infective cause for the granulomatous reaction we think that this morphological appearance is sufficiently distinct as to be considered a separate disease entity.

The main distinguishing histological feature is an inflammatory reaction composed of discrete granulomas confined to the lobules. This has been seen in all the reported cases, with the occasional occurrence of microabscesses, particularly when sheets of epithelioid cells are present. Other changes have been seen; ductular dilatation, ${ }^{1-3}$ squamous metaplasia, ${ }^{36}$ a foreign-body reaction around keratin flakes, ${ }^{6}$ and ductular inflammation. ${ }^{6}$ This last appearance, seen in two of our cases, probably represents an early stage in the progression of the inflammation and may provide a clue to the pathogenesis; damage to ductular epithelium whether by infection, trauma or a chemicallyinduced inflammation would allow luminal secretion to escape into the lobular connective tissue, thereby stimulating a granulomatous response, with resulting further damage to lobular structures.

Although the lesion is confined to young parous women, we have found no clinical relation with breast feeding or hormonal contraceptive use. None of the patients breast fed but we do not know if hormonal means of milk suppression were used. Follow-up details after excision of the mass have been presented in some of the case reports in the literature ${ }^{34}$ and have suggested that wound infection is a frequent problem. Our observations support this, three of five patients developing superficial infective problems, and one developing a recurrence within the breast. Steroid therapy has been recommended before surgical excision' and steroids were used with some effect after the second excision in case 7 .

There is very little evidence in the reported cases to suggest a distinct aetiology for granulomatous mastitis. Kessler and Wolloch, ${ }^{1}$ because of the morphological resemblance to granulomatous orchitis, suggested an immune aetiology but DeHertogh et al $^{9}$ found no immune dysfunction in their reported case. The morphological features seen in immunemediated inflammation; a predominantly plasma cell infiltrate, lymphoid aggregates with germinal centres and a vasculitis, were not present in any of the seven cases examined and in none of those previously reported. Solitary lesions with microabscess formation and a high proportion of postoperative infective complications does suggest a purely infecro tive aetiology. Unfortunately, no confirmatory bac-? teriology is available. Until further studies on the immune status of the patients with granulomatous mastitis and microbiological studies on the excised tissue are reported, any suggestions as to its aetiology are speculative.

Inflammatory breast lesions of this kind may be clinically mistaken for malignancy ${ }^{10}$ particularly if reactive draining lymph nodes are enlarged. Only one of our patients had tender nodes but in none of the cases were they enlarged. Certainly, carcinoma should not be excluded on clinical grounds alone, but we feel that on subsequent histology the correct diagnosis can be made. The differentiation of granulomatous mastitis from most of the other chronic inflammatory lesions of the breast should be possible on histological grounds; in particular the granulomas lack the caseation seen in tuberculous infection, the predominance of plasma cells in plasma cell mastitis and foreign or oily material in oleogranuloma, but sarcoidosis of the breast would give much the same histological picture and in the absence of systemic disease could easily be confused with granulomatous mastitis.

Granulomatous mastitis as a distinct morphological entity but of as yet unknown aetiology, deserves wider recognition by practising diagnostic pathologists. 
We would like to thank Drs JAH Finbow and MEA Powell for allowing us to use two of their cases, Dr Powell for advice and criticism, the secretarial help of Mrs G Holmes, and Dr K Sidky for translating from the German.

\section{References}

' Kessler E, Wooloch Y. Granulomatous mastitis: a lesion clinically simulating carcinoma. Am J Clin Pathol 1972;58:642-6.

${ }^{2}$ Cohen C. Granulomatous mastitis: a review of 5 cases. $S$ Afr Med J 1977;52:15-16.

${ }^{3}$ Koelmeyer TD, MacCormick Dem. Granulomatous mastitis. Aust NZ J Surg 1976;46:173-6.

4 Brown LK, Tang PHL. Post-lactational tumoral granulomatous mastitis: a localised immune phenomenon. Am J Surg 1979;138:326-9.
${ }^{5}$ Azzopardi JG. Problems in breast pathology. London: WB Saunders, 1978:400.

- Adair FE. Plasma cell mastitis-a lesion simulating mammary carcinoma. Arch Surg 1933;26:735-49.

' Schultz A. Handbuch der pathologischem Anatomie Vol II, part 2. Berlin: Julius Springer, 1933:142-50.

${ }^{8}$ Miller F, Seidman I, Smith CA. Granulomatous mastitis. NY State J Med 1971;71:2194-5.

- DeHertogh DA, Rossof AH, Harris AA, Economou SG. Prednisone management of granulomatous mastitis. $N$ Engl J Med 1980;308:799-800.

${ }^{10}$ Milward TM, Gough MH. Granulomatous lesions in the breast presenting as carcinoma. Surg Gynaecol Obstet 1970;130:478-82.

Requests for reprints to: Dr A Fletcher, Department of Pathology, Clinical Sciences Building, Leicester Royal Infirmary, PO Box 65, Leicester LE2 7LX, England. 